\title{
The Relationship Between the Knowledge Levels of Elderly Individuals on the COVID-19 Outbreak and Their Preventive Practices
}

\author{
Fuat YALMAN', Betül AKALIN², Tekin SANCAR ${ }^{3}$
}

\begin{abstract}
The main purpose of this study is to analyze the knowledge levels and preventive practices of the elderly people regarding the COVID-19 pandemic and to test the structural relationship between the knowledge levels and preventive practices towards COVID-19 pandemic with structural equation modeling. The population of the study consisted of patients over the age of 60 and their relatives who received health services from pharmacies operating in Sakarya city center. The data were collected personally by the researcher using the face-to-face survey technique. The total number of questionnaires evaluated and used in data analysis is 680. SPSS and AMOS package programs were used in the analysis of the data. Descriptive statistics, independent sample t-test, ANOVA analysis and structural equation modeling were applied to the data. Elderly individuals had a high level of knowledge and preventive practices regarding the COVID-19 outbreak. In addition, it was found that the preventive practices for the COVID-19 pandemic were higher in elderly women than in old men, regular drug users compared to non-users, and those with moderate general health status compared to those with low levels. Structural equation analysis revealed that the positive relationship between COVID-19 knowledge level and preventive practices for the COVID-19 outbreak has an acceptable fit index. It has been observed that there is a reciprocal and positive relationship between COVID-19 knowledge level and preventive practices towards COVID-19.
\end{abstract}

Keywords: Elderly Individuals, Knowledge Level, Preventive Practices, COVID-19

\section{Yaşlı Bireylerin COVID-19 Salgınına Yönelik Bilgi Düzeyleri ile Önleyici Uygulamaları Arasındaki İlişki}

\author{
Özet \\ $\mathrm{Bu}$ çalışmanın temel amacı, yaşlı bireylerin COVID-19 salgınına yönelik bilgi düzeyleri ile önleyici \\ uygulamalarını analiz etmek ve COVID-19 salgınına yönelik bilgi düzeyleri ile önleyici uygulamaları \\ arasındaki yapısal ilișkiyi yapısal eșitlik modellemesi ile test etmektir. Araştırmanın evrenini Sakarya il \\ 1Dr. Öğr. Üyesi, Düzce Üniversitesi, İşletme Fakültesi, Sağllk Yönetimi Bölümü, Düzce \\ İlgili yazar e-posta/Corresponding author e-mail: fuatyalman@duzce.edu.tr ORCID No: 0000-0002-1041-1837 \\ ${ }^{2}$ Dr. Öğr. Üyesi, Sağlık Bilimleri Üniversitesi, Sağlık Yönetimi Bölümü, İstanbul \\ e-posta: betul.akalin@sbu.edu.tr ORCID No: 0000-0003-0402-2461 \\ ${ }^{3}$ Dr., T.C. Sağlık Bakanlığı, Üst Düzey Yönetici, İdari Birim, İstanbul \\ e-posta: tekin.sancarr@gmail.com ORCID No: 0000-0002-5277-3449
}

Bu makaleye atıf yapmak için- To cite this article

Yalman, F., Akalın, B. and Sancar, T. (2021). The Relationship between the Knowledge Levels of Elderly Individuals on the COVID-19 Outbreak and their Preventive Practices. Journal of Disaster and Risk, 4(2), 224-236. 
merkezinde faaliyet gösteren eczanelerden sağlık hizmeti alan 60 yaş üstü hasta ve hasta yakınları oluşturmuştur. Veriler yüz yüze anket tekniği ile araştırmacı tarafından bizzat toplanmıştır. Değerlendirmeye alınan ve verilerin analizinde kullanılan toplam anket sayısı 680'dir. Verilerin analizinde SPSS ve AMOS paket programları kullanılmıştır. Verilere tanımlayıcı istatistikler, bağımsız örneklem t testi, ANOVA analizi ve yapısal eşitlik modellemesi uygulanmıştır. Yaşlı bireylerin COVID-19 salgınıyla ilgili bilgi düzeyleri ve önleyici uygulamaları yüksek düzeydeydi. Ayrıca yaşlı kadınların yaşlı erkeklere göre, düzenli ilaç kullananların kullanmayanlara göre ve genel sağlık durumu orya düzeyde olanların düşük düzeyde olanlara göre COVID-19 salgınına yönelik önleyici uygulamaları daha yüksek bulunmuştur. Yapısal eşitlik analizi, COVID-19 bilgi düzeyi ile COVID-19 salgınına yönelik önleyici uygulamalar arasındaki olumlu ilişkinin kabul edilebilir bir uyum indeksine sahip olduğunu ortaya koymuştur. COVID-19 bilgi düzeyi ile COVID-19'a yönelik önleyici uygulamalar arasında karşılıklı ve pozitif bir ilişkinin var olduğu görülmüştür.

Anahtar Kelimeler: Yaşlı Bireyler, Bilgi Düzeyi, Önleyici Uygulamalar, COVID-19

\section{INTRODUCTION}

When the history of the world is examined, it has been seen that people are struggling with a wide variety of diseases, mass deaths and pandemic diseases are quite common in societies. The latest of this pandemic disaster was the Coronavirus caused by Severe Acute Respiratory Syndrome SARS-CoV-2, which was first seen in the livestock market in Wuhan, China's Hubei Province, in December 2019 and then spread to the whole world. -19 (COVID-19) disease. COVID-19 infection has spread rapidly all over the world since December 2019, when the first case was seen, and was declared as a pandemic by the World Health Organization (WHO) on March 11, 2020 (World Health Organization, 2020).

The psychological reactions that occur during the pandemic can range from extreme fear to indifference to fatalism. Some people adapt to the threat and experience less anxiety. In some cases, psychological effects can be severe and prolonged (URL-3). A study on the SARS pandemic have shown that psychological effects are not always short-lived, but can lead to severe and Since generalizations are made, the source should be cited permanent mental problems (Taylor, 2019). It has been emphasized that COVID-19 disease can be seen in individuals of all ages and the severity and mortality of the disease are associated with advanced age (Morley and Vellas, 2020). In addition, it is reported that elderly individuals are more susceptible to COVID-19 disease and constitute a risky group in terms of morbidity and mortality (Liu et al., 2020). The patient group with the highest mortality rate is patients over the age of 85 , and the mortality rate is reported to be $10-27 \%$ (Levine et al., 2020).

Physiological changes of aging, comorbid conditions such as heart and lung disease, hypertension, diabetes, and geriatric syndromes may negatively affect the prognosis of COVID-19 disease (AlZahrani, 2021). In addition, in the COVID-19 pandemic, which affects the whole world, psychosocial difficulties such as anxiety, fear, depression, decrease in cognitive functions can be seen in the elderly population due to curfew, social isolation, decreased physical activity, and increased dependence in meeting needs (Zhou et al., 2020). Therefore, more information is needed on the knowledge levels and preventive practices of elderly individuals regarding the COVID-19 outbreak and the psychosocial effects of the pandemic process on the elderly. The purpose of this research is to address the COVID-19 disease in the context of the elderly population and to determine the relationship between the knowledge levels of elderly individuals and their preventive practices regarding the COVID-19 outbreak. 


\section{LITERATURE REWIEV}

\subsection{COVID-19 Epidemiology in Elderly People}

Some disadvantaged groups experience the emotions caused by the pandemic more intensely. Among these, elderly individuals, whom death is common and defined as risk groups, occupational groups who do not have the chance of social isolation and have to continue their work in the pandemic environment, those who have to close their workplaces in certain sectors those who are dismissed for an open period and are permanently dismissed. These individuals experience feelings of helplessness and despair, together with a serious stress burden of facing a serious threat of death, infecting loved ones without realizing it, losing their standard of living, not being able to meet their basic needs, or being under a burden of debt (URL- 2).

The COVID-19 pandemic has caused millions of people to become infected and many to die worldwide. There is a possibility of transmission of COVID-19 infection in all age groups, but individuals of middle age and older age groups were the most affected by this virus. In a study based on Chinese data, the rates of hospitalization with the diagnosis of COVID-19 increased with age; this ratio is reported to be $1 \%$ for 20 to 29 years old, $4 \%$ for 50 to 59 years old, and $18 \%$ for those over 80 years old (Verity et al., 2020). In addition, COVID-19 is reported to be more severe in individuals with chronic diseases such as the elderly, diagnosed with cancer, suppressed immune system, hypertension, COPD, and asthma, and these individuals have a high risk for mortality (Rothan and Byrareddy, 2020; Morley and Vellas, 2020). Similarly, studies conducted in China reported that the mortality rate was $2.3 \%$ for patients, $87 \%$ of whom were between the ages of $30-79,8 \%$ for those aged $70-79$, and $14.8 \%$ for those aged 80 and over (Liu et al., 2020 ; Zhou et al., 2020). In another study, the admission rate to the intensive care unit was $8.1 \%-18.8 \%$ and case fatality rate of individuals aged $65-74$ years was $2.7 \%-4.9 \%$, while between the ages of 75-84, the intensive care admission rate was $4.3-10.5 \%$ and case death rate was It has been reported to vary between $10.5 \%$ and $31 \%$ (Liu et al., 2020).

Niu et al. (2020) reported that the most common comorbid conditions in elderly individuals diagnosed with COVID-19 were hypertension (48.8\%), COPD (29.0\%), coronary heart disease (16.1\%), diabetes (9.7\%) and cerebrovascular disease (6.5\%). According to the data of the Disease Control and Prevention Center; It has been stated that the rate of hospitalization of those over 65 years of age with at least one chronic disease in the USA is $41.7 \%-44.5 \%$, while the rate of hospitalization for those without chronic disease varies between $16.8 \%$ and $18.3 \%$ (Al-Zahrani, 2021). In a study conducted in England, the mortality rate was found to be $5.1 \%$ in patients with COVID-19 between the ages of $60-79$ who have comorbidities, and $9.3 \%$ in patients over 80 years old (Nikolich-Zugich et al., 2020). In Turkey, according to the Ministry of Health data; approximately $75 \%$ of patients hospitalized in intensive care due to COVID-19 disease are over the age of 60 . In addition, it has been reported that $68.8 \%$ of the patients who lost their lives and $63.3 \%$ of the patients who were treated in the intensive care unit were diagnosed with hypertension (Işık, 2020).

\subsection{Psycho-Social Status of the Elderly During the COVID-19 Pandemic Process}

One of the most effective methods of controlling the COVID-19 pandemic is restrictions such as isolation, quarantine, and curfew. In cases where curfew and staying at home are compulsory, individuals may experience problems in psycho-social aspect in daily life. While individuals are protected from COVID-19 on the one hand, they expect to take precautions regarding the transmission routes of COVID-19 first, and then to meet their basic and mandatory needs as well as their safety and assistance needs in order to protect their psychosocial health (Disabled and Elderly Services General Directorate, 2020). 
At the same time, it has been observed that the COVID-19 pandemic, which affects the whole world, brings a significant psychosocial burden on the elderly population (Hantke \& Gould, 2020). As a new disease and global health problem, situations such as the rate of spread of the virus, incubation time, high number of infected individuals, high morbidity and mortality and the possibility of contact with individuals infected with COVID-19 cause inevitable anxiety and fear in the elderly population (LaHue et al., 2020). Especially in our country recently, with the new regulations (curfew, staying at home as much as possible, protecting social distance, the obligation to use a mask) at the social level by the COVID-19 Scientific Committee, the Ministry of Health and the country's administration, spending most of the day at home, both national Continuous followup of international news on channels such as social media and television caused an increasing anxiety and fear in elderly people against COVID-19 due to its unexpected and life-threatening nature (Ergör, 2020).

In addition, governments around the world are promoting social distancing as part of their strategies to combat COVID-19. However, the road from social distance to social isolation is quite short. Studies show that social isolation is associated with increased inactivity, smoking, alcohol abuse, unhealthy diet, depression, introversion, poor social skills, and post-traumatic stress disorder, leading to a higher risk of cardiovascular disease, dementia, and premature death, especially in older people (Douglas et al., 2020, Razai et al., 2020).

Infection outbreaks cause individuals and societies to experience deep psycho-social problems. During pandemic periods, people may experience situations such as the fear of being sick and death, helplessness, anxiety, anxiety, panic and stigma (Hall and Chapman, 1995). The COVID-19 outbreak is also likely to cause individuals to face psychological problems such as panic disorder, anxiety, and depression (Qui et al., 2020; Torun, 2020; Wang et al., 2020). In the COVID-19 process, it was aimed to reduce the spread of the virus and the virus-related mortality rate with the curfew restriction for the elderly. This practice, which has greatly contributed to the fight against COVID-19, is likely to have negative effects on the mental health, functionality and physical health of the elderly as time passes (Courtin \& Knapp, 2017).

\section{METHOD}

\subsection{Ethical Approval}

Prior to conducting the study, we obtained informed consent from the participants. This research was carried out with the ethical approval of University Scientific Research and Publication Ethics Committee (Date: 14.01.2021, decision no: 2021/32). Quantitative research methodology was used because it is suitable for the purpose and main problem of the research and the analysis of the data set was performed by using SPSS 26 and AMOS 24 statistical analysis programs.

\subsection{Participants}

The research was carried out with a society-based data collection method on patients over the age of 60 and their relatives who received health services from pharmacies operating in the city center of Sakarya. Non-random sampling method was used due to its easy accessibility. Participants were required to have applied to any pharmacy and voluntarily participated in a face-to-face survey.

\subsection{Research Design and Procedure}

The society-based cross-sectional study design was used. The research was carried out on five pharmacies operating in Sakarya city center. The data of the study were collected weekly during the period characterized as the second wave (Autumn of 2020) of the COVID-19 pandemic (URL4). This research is a prospective cross-sectional study conducted through a structured questionnaire from January 15 to March 15, 2021. It was carried out with the consent of all participants. 


\subsection{Measurements of Variables}

We applied the Turkish version of a ten items Likert-type COVID-19 knowledge level scale (Ahmed et al., 2020). The measuring tool has been found to provide high reliability for the study sample $(\alpha=0.822)$. And then, We applied the turkish version of a seven items Likert-type preventive practices towards COVID-19 scale (Asemahagn, 2020). The measuring tool has been found to provide high reliability for the study sample $(\alpha=0.881)$.

In the first stage, permission was requested from the researchers who developed the original scales for the adaptation process and their approval was obtained. The scales were translated into Turkish separately by 3 experts who know both the language of the original scale and Turkish language very well. In the second stage, the translations made by the authors and the translation group consisting of experts were compared. While making the comparison, each item was examined whether the translations were appropriate in terms of intended meaning. The third stage is the provision of the previous stage. At this stage, the scales translated into Turkish were given to a group of 3-5 people who are experts in the language of the original scale and independent from the experts in the second stage and these experts were asked to translate the scales from Turkish back to the original language. Later, the original expression of each item was compared one-to-one with the expression resulting from this translation. With the translation in the third stage, it was seen that the original scale was appropriate.

The concept of language equivalence is also named as language validity in the literature. For this purpose, the original scale and the draft scale were applied to a group of at least 15 people who know the languages of both scales well. In the application process, first the original scale and then the Turkish scale were applied at two-week intervals. After the application, the total scores of each individual in the study group obtained from both the original scale and the Turkish scale were calculated, and it was observed that the Pearson correlation coefficient of the relationship between the two applications was significant $(\mathrm{p}<0.01)$ and the degree of coefficient was 0.83 which shows a very high degree of harmony.

\subsection{Data Analysis}

All statistical analyses were performed using IBM SPSS and AMOS. We performed frequency and percentage analysis for reporting demographic data of the participants. Additionally, independent samples $t$ test and analysis of variance (ANOVA) were used for comparing the continuous data averages. Then, path analyses, using structural equation modelling (SEM) in AMOS, were performed to assess different latent structure models of the relationship between the knowledge levels of elderly individuals on the COVID-19 outbreak and their preventive practices. Examined models were based on the results from previous research on factor structures of the relationship between the knowledge levels of elderly individuals on the COVID-19 outbreak and their preventive practices. Criteria for determining structural equation modelling analysis model fit and measurement invariance were based on conventional standards (Munro, 2005; Brown, 2015; Byrne, 2016). Specifically, adequate model fit for a confirmatory factor analysis model was defined by a chisquare/df value $<5$, Root Mean Square Error of Approximation (RMSEA) value $\leq 0.10$, Comparative Fit Index (CFI) $\geq 0.90$, Incremental Fit Index (IFI) values $\geq 0.90$, Tucker Lewis index (TLI) values $\geq 0.90$, Goodness of Fit Index (GFI) values $\geq 0.85$, Relative Fit Index (RFI) values $\geq$ 0.90 and Normed Fit Index (NFI) values $\geq 0.90$.

\section{RESULTS}

\subsection{Normality Distribution of Research Data}

When the number of observations is 29 or more, Kolmogorov-Smirnov Test is used for normality (Kalaycl, 2008). Therefore, Kolmogorov-Smirnov Test was used to determine whether the data showed a normal distribution and as a result of the analysis, it was seen that the data were not 
normally distributed. It is common to observe abnormal data in studies of this nature. Micceri (1989) states that normality is rare in social science studies that require the use of non-parametric tests. In addition, in cases where the number of subjects entering the analysis is high, it can be accepted that the variables meet the normality assumption according to the central limit theorem (Smidt et al., 2001). Therefore, analysis techniques with normal distribution were applied to all data.

\subsection{Demographic Findings}

A total of 680 participants' responses were considered for analysis of this study. Table 1 shows the demographic characteristics of the participants and t test and ANOVA test regarding COVID19 knowledge level and preventive practices towards COVID-19. It can be seen that $25 \%$ males and $75 \%$ females were the respondents for this study. Participants about two-thirds (61.3\%) had high school level and below. Participants stated that they mostly applied to public hospitals (69.9\%) when they experienced a health problem. The majority of the participants (86\%) stated that they had at least one chronic disease. The majority of the participants (82.4\%) stated that they used drugs regularly. The majority of the participants (60.9\%) expressed their general health status as moderate.

Table 1. Demographic Characteristics of The Study Participants $(n=680)$

\begin{tabular}{|c|c|c|c|c|c|c|}
\hline \multirow[b]{2}{*}{ Variables } & \multirow[b]{2}{*}{$\mathbf{N}$} & \multirow[b]{2}{*}{$\%$} & \multicolumn{2}{|c|}{ Knowledge Level } & \multicolumn{2}{|c|}{ Preventive Practices } \\
\hline & & & $\begin{array}{c}\text { t Test/ } \\
\operatorname{Anova}(t / F)\end{array}$ & $\mathbf{p}$ & $\begin{array}{c}\text { t Test/ } \\
\operatorname{Anova}(t / F)\end{array}$ & $\mathbf{p}$ \\
\hline \multicolumn{7}{|l|}{ Sex } \\
\hline Male & 170 & 25,0 & $-1.867^{a}$ & 0.062 & $-6.373^{a}$ & 0.000 \\
\hline Female & 510 & 75,0 & & & & \\
\hline \multicolumn{7}{|l|}{ Educational attainment } \\
\hline High school level and below & 417 & 61.3 & & & & \\
\hline College & 230 & 33.8 & $0.595^{b}$ & 0.618 & $0.307 \mathrm{~b}$ & 0.820 \\
\hline Master's degree & 28 & 4.1 & & & & \\
\hline Doctoral degree & 5 & 0.7 & & & & \\
\hline \multicolumn{7}{|l|}{ Most used hospital type } \\
\hline Public hospital & 475 & 69,9 & $3.329 \mathrm{~b}$ & 0.036 & $6.291^{b}$ & 0.002 \\
\hline University hospital & 70 & 10,3 & & & & \\
\hline Private hospital & 135 & 19,9 & & & & \\
\hline \multicolumn{7}{|l|}{ Presence of chronic diseases } \\
\hline Yes & 585 & 86.0 & $1.886^{\mathrm{a}}$ & 0.061 & $1.863^{\mathrm{a}}$ & 0.063 \\
\hline No & 95 & 14.0 & & & & \\
\hline \multicolumn{7}{|l|}{ Regular drug use } \\
\hline Yes & 560 & 82.4 & $-1.234^{\mathrm{a}}$ & 0.218 & $3.054^{\mathrm{a}}$ & 0.002 \\
\hline No & 120 & 17.6 & & & & \\
\hline
\end{tabular}


The Relationship Between the Knowledge Levels of Elderly Individuals on the COVID-19 Outbreak and Their Preventive Practice

\begin{tabular}{|c|c|c|c|c|c|c|}
\hline Too bad & 1 & 0.1 & \multirow{5}{*}{$0.472^{\mathrm{b}}$} & \multirow{5}{*}{0.756} & \multirow{5}{*}{$7.553^{\mathrm{b}}$} & \multirow{5}{*}{0.000} \\
\hline $\mathrm{Bad}$ & 14 & 2.1 & & & & \\
\hline Medium & 414 & 60.9 & & & & \\
\hline Good & 179 & 26.3 & & & & \\
\hline Very good & 72 & 10.6 & & & & \\
\hline
\end{tabular}

a Independent sample t test

b ANOVA test

\subsection{Descriptive findings related to factors}

Descriptive statistics, averages, standard deviations, reliability coefficients, number of participants and variance values are given in Table 2 .

Table 2. Descriptive Statistics Related to Factors

\begin{tabular}{lccccc}
\hline Factors & N & Mean & $\begin{array}{c}\text { Standard } \\
\text { Deviation }\end{array}$ & Variance & $\begin{array}{c}\text { Cronbach's } \\
\text { alpha }\end{array}$ \\
\hline COVID-19 Knowledge Level & 680 & 4.2267 & 0.53623 & 0.288 & 0.822 \\
\hline $\begin{array}{l}\text { Preventive Practices towards } \\
\text { COVID-19 }\end{array}$ & 680 & 2.6775 & 0.87047 & 0.758 & 0.881 \\
\hline
\end{tabular}

As a result of the confirmatory factor analysis, the overall reliability coefficient was found to be Alpha $=0.822$. Because $0.80 \leq \alpha<1.00$, the scale is highly reliable. Ensuring validity and reliability shows the existence of a structural relationship between COVID-19 knowledge levels and preventive practices towards COVID-19 of elderly individuals.

\subsection{The Model Fit Measures}

A total of 17 questions in this study constitute three latent variables. From the 17 questions, 2 items were removed because of poor communality extraction; finally, a total of 15 items/questions are taken into consideration to proceed further. The model fit was tested by different model fit indicators, which is given in Table 3.

Table 3. Model fit measures

\begin{tabular}{lccc}
\hline Measure & Estimate & Threshold & Interpretation \\
\hline CMIN/DF & 3.604 & Between 1 and 5 & Acceptable range \\
\hline CFI & 0.945 & $\geq 0.90$ & Within range \\
\hline GFI & 0.944 & $\geq 0.85$ & Within range \\
\hline NFI & 0.926 & $\geq 0.90$ & Within range \\
\hline RMSEA & 0.062 & $\leq 0.10$ & Within range \\
\hline RMR & 0.055 & $<0.08$ & Within range \\
\hline TLI & 0.932 & $\geq 0.90$ & Within range \\
\hline
\end{tabular}


From Table 3, it can be summarized that this study items of the latent variables pass through all the major model fit indicators suggested by Munro (2005), Brown (2006) and Byrne (2001).

\subsection{The Results of The Measurement Model}

It was assumed that the reasoning between the variables in the research model can be explained. Confirmatory factor analysis was performed to test the validity of the scales used, and the structure of all scales were verified. Figure 1 shows the confirmatory factor analysis results and model fit for the variables of COVID-19 knowledge level and preventive practices towards COVID19.

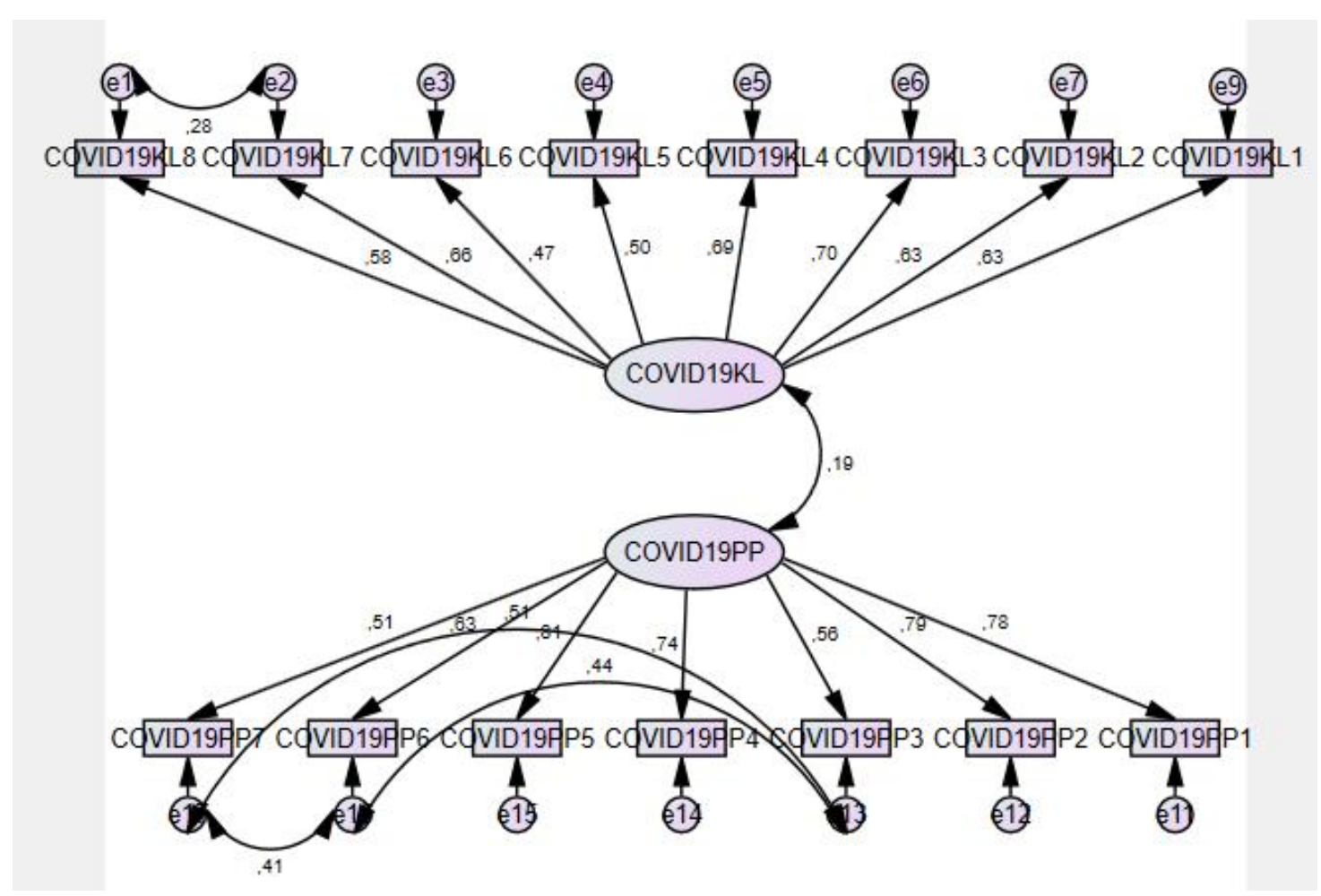

Figure 1. The results of the full model

The results of the analysis performed to test the reliability and validity of the measurement model are shown in Table 3. Table 3 expresses the goodness of fit values of the measurement model. The estimates or standard loading of each item ranges from 0.51 to 0.81 . According to Harrington (2009), the standard factor loading estimates should be not less than 0.30 (ideally 0.70 or higher). Table 4 shows that the cronbach's $\alpha$ coefficients are above the minimum criterion $(>0.60)$. Finally, for average variance extracted (AVE) and construct reliability (CR), Fornell and Larcker (1981) stated that although the AVE value is below 0.50, if the CR value is above 0.70, AVE values below 0.50 can be accepted. In addition, Table 4 shows that the structures applied in the research meet the reliability and validity criteria. In addition, covariances were created between some latent variables in the same group in order to increase the goodness of fit values, and as a result, the model was accepted to be supported by the data.

Since the CR vavues are greater than 0.7 , the factors have high construct reliability. The fit values examined show that the data fit the model well. Table 5 shows the results of the structural model. 
The Relationship Between the Knowledge Levels of Elderly Individuals on the COVID-19 Outbreak and Their Preventive Practice

Table 4. The Items' Estimate and The Constructs' Cronbach's $\alpha$, AVEs and CRs.

\begin{tabular}{|c|c|c|c|c|c|}
\hline Constructs & Items & Estimate & Cronbach's $\alpha$ & $\begin{array}{c}\text { Average } \\
\text { Variance } \\
\text { Extracted (AVE) }\end{array}$ & $\begin{array}{c}\text { Construct } \\
\text { Reliability (CR) }\end{array}$ \\
\hline \multirow{8}{*}{$\begin{array}{l}\text { COVID-19 } \\
\text { Knowledge } \\
\text { Level } \\
\text { (COVID19KL) }\end{array}$} & COVID19KL8 & .581 & \multirow{8}{*}{0.822} & \multirow{8}{*}{0.38} & \multirow{8}{*}{0.78} \\
\hline & COVID19KL7 & .663 & & & \\
\hline & COVID19KL6 & .473 & & & \\
\hline & COVID19KL5 & .498 & & & \\
\hline & COVID19KL4 & .687 & & & \\
\hline & COVID19KL3 & .697 & & & \\
\hline & COVID19KL2 & .632 & & & \\
\hline & COVID19KL1 & .629 & & & \\
\hline \multirow{7}{*}{$\begin{array}{l}\text { Preventive } \\
\text { Practices } \\
\text { towards } \\
\text { COVID-19 } \\
\text { (COVID19PP) }\end{array}$} & COVID19PP1 & .782 & \multirow{7}{*}{0.878} & \multirow{7}{*}{0.47} & \multirow{7}{*}{0.83} \\
\hline & COVID19PP2 & .786 & & & \\
\hline & COVID19PP3 & .559 & & & \\
\hline & COVID19PP4 & .740 & & & \\
\hline & COVID19PP5 & .812 & & & \\
\hline & COVID19PP6 & .628 & & & \\
\hline & COVID19PP7 & .514 & & & \\
\hline
\end{tabular}

Table 5. The Result of The Structural Model

\begin{tabular}{|c|c|c|c|c|c|c|}
\hline Hypothesis & Correlations & Estimate & S.E. & C.R. & $\mathrm{P}$ & Result \\
\hline \multicolumn{7}{|c|}{ Relationship between COVID-19 knowledge level and preventive practices towards COVID-19 } \\
\hline $\mathrm{H}_{1}$ & COVIDKL <-------> COVID19PP & .189 & .084 & 3.996 & $* * *$ & $\mathrm{H}_{1}$ supported \\
\hline
\end{tabular}

The obtained fit values show that the model fit is achieved. There is a positive relationship between COVID-19 knowledge level and preventive practices towards COVID-19. The increase in COVID-19 knowledge level causes an increase in preventive practices towards COVID-19 and the positive correlation between the COVID-19 knowledge level and preventive practices towards COVID-19 is confirmed.

\subsection{The Results of The Structural Model}

From the result, it is found that there is a positive relationship between COVID-19 knowledge level and preventive practices towards COVID-19 and the positive correlation between the COVID-19 knowledge level and preventive practices towards COVID-19 is confirmed. Thus, $\mathrm{H}_{1}$ is statistically supported. 


\section{DISCUSSION AND CONCLUSION}

Unhealthy information and virus-based panic are factors that negatively affect the psychology of individuals in this process. Giving the news of death caused by COVID-19 with the emphasis on the elderly threatens the instinct of life, which is one of the most basic motives of individuals. For this reason, elderly individuals become more fragile in the psycho-social sense. Expressing that they are very vulnerable to the COVID-19 pandemic may increase the anxiety and stress levels of the elderly and cause them to experience fear of death. While elderly individuals, who are identified with concepts such as sick and in need of care, may experience deep psychological problems as a result of negative emotions such as helplessness, powerlessness, uselessness, loneliness, hopelessness, and reluctance, curfew restrictions and home isolation practices can increase the elderly's feelings of loneliness and uselessness. In this regard, it is extremely important to take preventive measures for the elderly, to increase their individual skill level, to reduce their anxiety and to ensure that they do not feel alone in the fight against the process.

Morbidity and mortality are very high in elderly individuals in COVID-19 disease caused by SARS$\mathrm{CoV}-2$, which has become a pandemic. Based on the fact that $8.8 \%$ of the total population of our country consists of elderly individuals, it is important to evaluate the clinical characteristics of COVID-19 in the geriatric population, the effects of physiological changes and comorbid conditions on the prognosis of COVID-19 and the effects of the pandemic process on the cognitive and psychosocial health of elderly individuals. In addition, it can be ensured that the physical and psychosocial problems caused by the pandemic in elderly people can be reduced by comprehensively evaluating geriatric individuals, maintaining communication, providing information with clear and simple expressions, meeting the needs of elderly individuals during the discharge process and rehabilitation program, and planning appropriate nursing interventions in the entire process.

Studies have shown that knowledge, attitudes and behaviors for a particular infectious disease affect the severity of the disease, its spread severity, and the mortality rate. In the study conducted by Srichan et al. (2020) on COVID-19 in the Thai population, it was found that $73.4 \%$ of the participants had poor knowledge, $28.5 \%$ had poor attitude and $13.6 \%$ had high behavior. In the study conducted by Reuben et al. (2020) in Nigerian society, it was found that $99.5 \%$ of the participants had a high level of knowledge. In addition, it was found that $92.7 \%$ of the participants applied social distance / self-isolation, $96.4 \%$ gave importance to personal hygiene and $82.3 \%$ showed positive behavior by using a face mask. In the study conducted by Vijai and Joyce (2020) on the Indian society, it was stated that $89.9 \%$ of the respondents had a high level of knowledge about COVID-19, and newspaper and television news were seen as the highest source of information. In addition, it was determined that $87.7 \%$ of the participants used hand washing, $76.3 \%$ used antibacterial disinfectant and $82.6 \%$ used mask-wearing measures.

The individuals participating in the study were found to have moderate or high levels of COVID19 knowledge and preventive practices towards COVID-19, and the relationship between the COVID-19 knowledge levels and preventive practices towards COVID-19 was statistically significant. As a result, it is found that there is a positive relationship between COVID-19 knowledge level and the positive correlation between the COVID-19 knowledge levels and the preventive practices towards COVID-19 is confirmed. The increase in COVID-19 knowledge level causes an increase in preventive practices towards COVID-19. Contrary to the result of our study a study reported that knowledge scores showed an inverse correlation with fear scores $(p<0.001)$. In the same study Bangladeshi have reported significant self-isolation, positive preventive health behaviors related to COVID-19, and a moderate to high sense of fear of COVID-19 (Hossain, 2020). 
According to the results of this study, the COVID-19 knowledge level and preventive practices towards COVID-19 of the individuals participating in the research were moderate to high. The COVID-19 knowledge level are significantly associated with preventive practices towards COVID19. Elderly patients are the patient group most affected by COVID-19, and despite all the unknowns, age is the most important risk factor for this viral infection.

\section{REFERENCES}

Ahmed, M. A., Rehab, H. E., Mahdi, A. A., \& Maher, E. (2020). Knowledge and attitudes towards Middle East respiratory sydrome-coronavirus (MERS-CoV) among health care workers in South western Saudi Arabia. East Mediterr Health J., 26(4), 435-442. DOI:10.26719/emhj.19.079

Al-Zahrani, J. (2021). SARS-CoV-2 associated COVID-19 in geriatric population: A brief narrative review. Saudi J Biol Sci., 28(1), 738-743. DOI: 10.1016/j.sjbs.2020.11.001

Asemahagn, M. A. (2020). Factors determining the knowledge and prevention practice of healthcare workers towards COVID-19 in Amhara region, Ethiopia: a cross-sectional survey. Asemahagn TropicalMedicine and Health, 48, 72, 1-11. DOI:10.1186/s41182-020-00254-3

Brown, T. A. (2015). Confirmatory factor analysis for applied research (2nd Edition). New York: Guilford Press.

Byrne, B. M. (2016). Structural equation modeling with AMOS: Basic concepts, applications, and programming (3rd Edition). Lawrence Erlbaum Associates.

Douglas, M., Katikireddi, S.V., Taulbut, M., mckee, M., Mccartney, G. (2020) Mitigating the wider health effects of COVID-19 pandemic response. BMJ 369, m1557. DOI: 10.1136/bmj.m1557

Ergör, G. (2020). Koronavirüs pandemisinin düşündürdükleri. Türkiye Halk Sağlı̆̆ı Dergisi, 18(1), 99-108. DOI: $10.20518 /$ tjph.704476

Hantke, N. C., \& Gould, C. (2020). Examining older adult cognitive status in the time of COVID-19. J Am Geriatr Soc. 2020;00:1-2. DOI: 10.1111/jgs.16514

Harrington, D. (2009). Confirmatory Factor Analysis. New York: Oxford University Press, p.21-35

Hossain, M. A., Jahid, M. I. K., Hossain, K. M. A., Walton, L. M., Uddin, Z., Haque, M. O. et al. (2020). Knowledge, attitudes, and fear of COVID-19 during the Rapid Rise Period in Bangladesh. PLoS ONE, 15(9): e0239646, DOI: $10.1371 /$ journal. pone.0239646.

Işık, A. T. (2020). Geriatrik Olgularda COVID-19: Göz Ardı Edilmemesi Gereken Konular. Geriatrik Bilimler Dergisi, 3(1), 1-2.

Kalaycı, Ș. (2008). SPSS Uygulamalı Çok Değișkenli İstatistik Teknikleri (3. Baskı) Ankara: Asil Yayın Dağıtım.

LaHue, S. C., James, T. C., Newman, J. C., Esmaili, A. M., Ormseth, C. H., Ely, E. W. (2020). Collaborative delirium prevention in the age of COVID-19. J Am Geriatr Soc., 68(5), 947-949, DOI: 10.1111/jgs.16480.

Levine, S., Bonner, A., Perry, A., Melady, D., Unroe, K. T. et al. (2020). CoVID-19 in Older Adults: Transfers Between Nursing Homes and Hospitals. Jounal of Geriatric Emergency Medicine, 1(5), 1-7.

Liu, K., Chen, Y., Lin, R., \& Han, K. (2020). Clinical features of COVID-19 in elderly patients: A comparison with young and middle-aged patients. J Infect., 80(6), e14-e18, DOI: 10.1016/j.jinf.2020.03.005. 
Micceri, T. (1989). The unicorn, the normal curve, and other improbable creatures. Psychological Bulletin, 105, 156-166, DOI:10.1037/0033-2909.105.1.156.

Morley, J. E., \& Vellas, B. (2020). COVID-19 and older adults. J Nutr Health Aging., 24(4), 364-365. DOI:10.1007/s12603-020-1349-9.

Munro, B. H. (2005). Statistical Methods For Health Care Research (5th edition). Philadelphia: Lippincott Williams \& Wilkins.

Nikolich-Zugich, J., Knox, K. S., Rios, C. T., Natt, B., Bhattacharya, D., \& Fain, M. J. (2020). SARS-CoV-2 and COVID-19 in older adults: What we may expect regarding pathogenesis, immune responses, and outcomes. GeroScience, 42(2), 505-514. DOI: 10.1007/s11357-020-00186-0

Niu, S., Tian, S., Lou, J., et al. (2020). Clinical characteristics of older patients infected with COVID-19: A descriptive study. Arch Gerontol and Geriatr., 89, 1-5. DOI: 10.1016/j.archger.2020.104058

Razai, M. S., Oakeshott, P., Kankam, H., Galea, S., \& Stokes-Lampard, H. (2020). Mitigating the psychological effects of social isolation during the COVID-19 pandemic. BMJ 369: m1904. DOI: 10.1136/bmj.m1904 (Last Acceded: 15.04.2021)

Reuben, R. C, Danladi, M. M. A., Saleh, D. A., \& Ejembi, P. E. (2020). Knowledge, Attitudes and Practices Towards COVID-19: An Epidemiological Survey in North Central Nigeria. Journal of Community Health, DOI: 10.1007/s10900-020-00881-1.

Rothan, H. A., \& Byrareddy, S. N. (2020). The epidemiology and pathogenesis of coronavirus disease (COVID19) outbreak. J Autoimmun, 109, 102433. DOI: 10.1016/j.jaut.2020.102433 (Last Acceded: 10.05.2021)

Smidt, R. K., Levine, D. M., \& Ramsey, P. P. (2001). Applied Statistics. Prentice Hall.

Srichan, P., Apidechkul, T., Tamornpark, R., Yeemard, F., \& Khunthason, S. (2020). Knowledge, Attitude and Preparedness to Respond to the 2019 Novel Coronavirus (COVID-19) Among the Bordered Population of Northern Thailand in the Early Period of the Outbreak: A CrossSectional Study. The Lancet, DOI: $10.2139 /$ ssrn.3546046.

Taylor, S. (2019). The Psychology of Pandemics: Preparing for the Next Global Outbreak of Infectious Disease. Newcastle upon Tyne: Cambridge Scholars Publishing.

Verity, R., Okell, L. C., Dorigatti, I., et al. (2020). Estimates of the severity of coronavirus disease 2019: a model-based analysis. Lancet Infect Dis, DOI: 10.1016/S1473-3099(20)30243-7

Vijai, C. \& Joyce, D. (2020). Novel Coronavirus (COVID-19) Knowledge and Awareness: A Survey of Thiruvallur District, Tamilnadu. Shanlax International Journal of Management, 8(1), 69-76. DOI: 10.34293/management.v8i1.322.

World Health Organization WHO (2020). Announces COVID-19 Outbreak a Pandemic. Available from: https://www.euro.who.int/en/health-topics/health-emergencies/coronavirus-covid

19/news/news/2020/3/whoannounces-covid-19-outbreak-a-pandemic (Last Acceded: 4.04.2020).

Zhou, F., Yu, T., Du, R., et al. (2020). Clinical course and risk factors for mortality of adult inpatients with COVID-19 in Wuhan, China: a retrospective cohort study. The Lancet, 395(102299), 1054-1062. DOI: 10.1016/S0140-6736(20)30566-3 (Last Acceded: 16.10.2021).

URL- 1: Engelli ve Yaşlı Hizmetleri Genel Müdürlüğü (2020). 65 Yaş Üzeri Yaşlılar Ve Kronik Hastalığı Bulunan Yaşlllara Yönelik Koronavirüs (COVID-19) Bilgilendirme Rehberi - VI. https://ailevecalisma.gov.tr/media/46206/rehber-eyhgm-65-yas-uzeri-yaslilar-ve-kronik-hastalara yonelik-koronavirus-bilgilendirme-rehberi.pdf (Last Acceded: 15.06.2021) 
The Relationship Between the Knowledge Levels of Elderly Individuals on the COVID-19 Outbreak and Their Preventive Practice

URL- 2: Taştan, C., Tekin, H. H., Çetinöz, E., \& Demirden, A. (2020). Kovid-19 Salgını ve Sonrası Psikolojik ve Sosyolojik Değerlendirmeler. Polis Akademisi Yayınları, Ankara. ISBN: 978-605-7822-35-2. https://www.pa.edu.tr/Upload/editor/files/Covid Sonras\%C4\%B1_Psik Sos Degerlendirmeler.pdf (Last Acceded: 15.07.2021)

URL-3: Tükel, R. (2020). COVID-19 Pandemi Sürecinde Ruh Sağlı̆̆ı Türk Tabipler Birliği COVID-19 Pandemisi Altıncı Ay Değerlendirme Raporu. Available from: https://www.ttb.org.tr/kutuphane/covid19rapor 6/covid19-rapor 6_Part71.pdf (Last Acceded: 17.11.2021).

URL-4: Uluslararası Çalışma Örgütü (2021). Araştırma Notu - İkinci Dalga COVID-19 Önlemlerinin Türkiye'de İstihdam Üzerindeki Etkisi. https://www.ilo.org/wcmsp5/groups/public/---europe/---rogeneva/---ilo-ankara/documents/publication/wcms 775756.pdf (Last Acceded: 17.11.2021). 